\title{
POLA CEMARAN BAHAN KIMIA DI ALIRAN SUNGAI RIAM KANAN KABUPATEN BANJAR
}

\author{
Munawar Raharja, Zulfikar Ali As, Sulaiman Hamzani \\ Poltekkes Kemenkes Banjarmasin Jurusan Kesehatan Lingkungan \\ Jl. H. Mistar Cokrokusumo No. 1A Banjarbaru Kalimantan Selatan 70714 \\ E-mail : munawarraharja76@gmail.com
}

\begin{abstract}
The Pattern Of Chemical Pollution In Riam Kanan River, Kabupaten Banjar. Riam Kanan river is utilized by the community for various needs, such as for households, cultivation of fish in keramba, mining of sand and coral. This research aimed to know the pattern of chemical pollution in Riam Kanan river, which was related to flow direction, pollutant source especially keramba of fish, and flow rate, with the parameters of $p H$, dissolved oxygen (DO) and biochemical oxygen demand (BOD). The research was conducted by observation, field measurement and laboratory examination. Water sampling was done at 8 location: The reservoir of Riam Kanan, PLTA Ir. P. M. Noor, Tambela Sari Village, Tambela Village, Awang Bangkal Village, Mandikapau Village, The Dam of Irigation Karang Intan, and Sungai Asam village with length of rivers $13.41 \mathrm{~km}$. The results showed that the flow of river ranged from 15.53 to $147.72 \mathrm{~m}^{3} / \mathrm{sec}$. The $\mathrm{pH}$ of water ranged $6.13-6.70 . \mathrm{DO}$ levels ranged 2.34 - $6.95 \mathrm{mg} / \mathrm{L}$ while BOD levels ranged $1.16-2.91 \mathrm{mg} / \mathrm{L}$. The utilization of river flow for keramba of fish, households activities and sand and coral excavations had affected the quality of water, especially the level of dissolved oxygen along the river flow.
\end{abstract}

Keywords: Pattern of pollution; river flow; $\mathrm{pH}$; dissolved oxygen (DO); biochemical oxygen demand (BOD)

\begin{abstract}
Abstrak: Pola Cemaran Bahan Kimia Di Aliran Sungai Riam Kanan Kabupaten Banjar. Sungai Riam Kanan dimanfaatkan masyarakat untuk berbagai kebutuhan, diantaranya untuk rumah tangga, budidaya ikan keramba, penambangan pasir dan koral. Penelitian ini bertujuan untuk mengetahui pola cemaran bahan kimia di aliran sungai Riam Kanan dikaitkan dengan arah aliran, sumber pencemar terutama keramba ikan, dan debit aliran, dengan parameter $\mathrm{pH}$, oksigen terlarut (DO) dan kebutuhan oksigen biokimia (BOD). Penelitian dilaksanakan dalam bentuk observasi, pengukuran di lapangan dan pemeriksaan di laboratorium. Pengambilan sampel air dilakukan pada 8 lokasi : Waduk Riam Kanan, PLTA Ir. P. M. Noor, Desa Tambela Sari, Desa Tambela, Desa Awang Bangkal, Desa Mandikapau, Bendungan Irigasi Karang intan, dan Desa Sungai Asam dengan panjang aliran sungai yang diteliti $13,41 \mathrm{~km}$. Hasil penelitian menunjukkan debit aliran sungai berkisar antara 15,53 - 147,72 m³/detik, pH air berkisar antara 6,13 6,70. Kadar DO berkisar antara 2,34 - 6,95 mg/L sedangkan kadar BOD berkisar antara $1.16-2,91 \mathrm{mg} / \mathrm{L}$. Pemanfatan aliran sungai untuk keramba ikan, rumah tangga dan galian pasir dan koral berpengaruh terhadap kualitas air sungai, terutama terhadap kadar oksigen terlarut di sepanjang aliran sungai.
\end{abstract}

Kata kunci: Pola cemaran; aliran sungai; pH; oksigen terlarut (DO); kebutuhan oksigen biokimia (BOD)

\section{PENDAHULUAN}

Air sungai Riam Kanan tidak hanya dimanfaatkan masyarakat sebagai sumber air bersih, tetapi dengan segala kekayaan di dalamnya seperti berbagai jenis ikan, bahan galian seperti, pasir dan koral membuat banyak masyarakat di pesisir sungai menggantungkan kehidupan mereka dari aliran sungai tersebut.

Beberapa tahun terakhir, di sepanjang aliran sungai Riam Kanan aktivitas budidaya ikan dalam keramba lebih berkembang dibandingkan dengan aktivitas penambangan bahan galian. 
Perkembangan sektor perikanan ini memberikan pemasukan bagi daerah dan masyarakat, namun di sisi lain juga dapat menyebabkan pencemaran sungai. Sisa pakan, kotoran dan bangkai ikan merupakan sumber pencemaran air sungai. Pada musim kemarau tahun 2012 dan 2014, penurunan debit sungai menyebabkan kematian massal ikan dan mencemari sungai hampir di seluruh Kecamatan Karang Intan[1].

Alam sebenarnya memiliki kemampuan untuk memperbaiki kondisi tercemar ke kondisi alamiah melalui mekanisme pembersihan (self purification). Oksigen dari permukaan sungai dilarutkan dan digunakan mikroorganisme untuk menguraikan bahan organik dan anorganik secara aerob dan kadar bahan pencemar akan mengalami penurunan bila tidak ada tambahan beban pencemar yang memasuki badan air, hal ini membuktikan bahwa sungai mempunyai kemampuan untuk self purification [2]. Dengan mekanisme ini, seharusnya semakin ke hilir jumlah zat pencemar akan berkurang dan kondisi air akan semakin membaik.

Penelitian ini bertujuan untuk menggambarkan pola cemaran bahan kimia di aliran sungai Riam Kanan berdasarkan posisi sungai, debit aliran dan sumber pencemar terhadap kualitas air dengan parameter $\mathrm{pH}$, DO dan BOD. Hasil penelitian diharapkan dapat dijadikan dasar untuk menganalisis tingkat pencemaran air pada aliran sungai Riam Kanan.

\section{BAHAN DAN CARA PENELITIAN}

Jenis penelitian yang digunakan observasi dengan rancangan cross sectional. Kecendrungan pola cemaran bahan kimia digambarkan dengan parameter $\mathrm{pH}, \mathrm{DO}$, dan BOD ,serta dianalisis berdasarkan posisi sungai, debit aliran dan sumber pencemar terutama aktivitas keramba.

Penelitian dilaksanakan di aliran Sungai Riam Kanan Kabupaten Banjar pada jarak 13,41 kilometer. Lokasi pengambilan sampel ditentukan berdasarkan arah aliran sungai dan pemanfaatan aliran sungai. Populasi sampel adalah seluruh air disepanjang aliran sungai Riam Kanan Kabupaten Banjar dan sampel adalah air sungai pada lokasi pengambilan sampel yang ditentukan secara Snow-ball sampling. Titik pengambilan sampel ditentukaan berdasarkan debit aliran sungai, dengan 2 periode pengambilan sampel[3][4]. Parameter yang diukur adalah $\mathrm{pH}$, DO dan BOD dengan metode analisis mengacu kepada SNI.

Data hasil pengukuran dan pemeriksaan disajikan dalam bentuk tabel dan narasi, untuk menggambarkan hubungan variabel bebas berupa: posisi sungai (jarak antar lokasi pengambilan sampel), sumber pencemar (jumlah keramba), dan faktor yang mempengaruhi (debit aliran) dengan variabel terikat berupa parameter $\mathrm{pH}, \mathrm{DO}$ dan BOD dilakukan dengan analisis korelasi spearman. Untuk mengambarkan pola kadar DO dan BOD dengan sumber pencemar (jumlah keramba ikan) dilakukan dengan analisis spasial dengan program Quantum GIS.

\section{HASIL PENELITIAN DAN PEMBAHASAN}

Sungai Riam Kanan adalah anak Sungai Martapura, yang mengalir dari Desa Tambela Sari Kecamatan Aranio hingga Desa Pingaran Ulu Kecamatan Astambul. Aliran Sungai Riam Kanan Riam Kanan memiliki dengan panjang $70 \mathrm{~km}$ dan lebar rata-rata $50 \mathrm{~m}[5][6]$. Aliran sungai Riam Kanan memiliki nilai strategis, karena terdapat Waduk Riam Kanan, pembangkit tenaga listrik (PLTA), dan Bendungan Karang Intan.

Berdasarkan hasil survei pada lokasi penelitian, maka ditetapkan lokasi pengambilan sampel sebanyak 8 tempat, yaitu 1) Waduk Riam Kanan, 2) PLTA Ir. P. M. Noor, 3) Desa Tambela Sari, 4) Desa Tambela, 5) Desa Awang Bangkal, 6) Desa Mandikapau, 7) Bendungan Irigasi Karang intan, dan 8) Desa Sungai Asam. Jarak aliran sungai yang diditeliti $13,41 \mathrm{~km}$. (Gambar 1). 


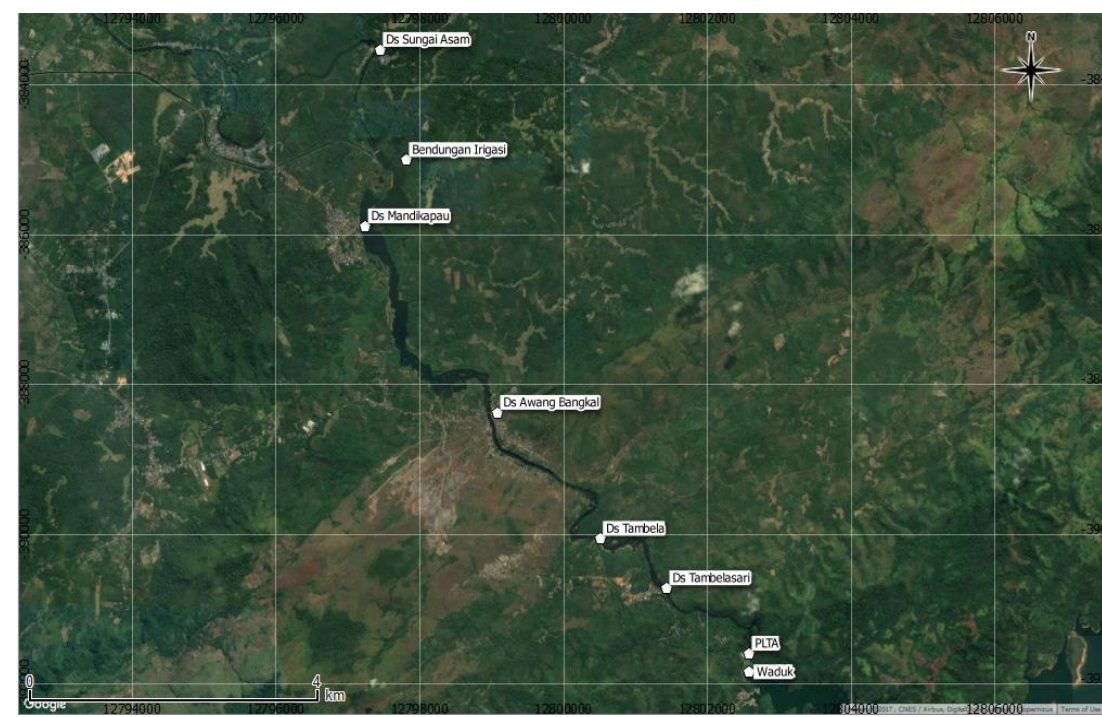

Gambar 1. Peta Lokasi Pengambilan Sampel Air (Citra satelit Google,2017)

Hasil pemeriksaan parameter lapangan dan laboratorium diperoleh data sebagai berikut :

Tabel 1. Hasil Pemeriksaan Pada Lokasi Penelitian

\begin{tabular}{|c|c|c|c|c|c|c|c|}
\hline \multirow{3}{*}{ No. } & \multirow{3}{*}{$\begin{array}{c}\text { Lokasi Pengambilan } \\
\text { Sampel }\end{array}$} & \multicolumn{6}{|c|}{ Hasil Pemeriksaan (Rata-rata) } \\
\hline & & \multirow{2}{*}{$\begin{array}{c}\text { Debit } \\
\left(\mathrm{m}^{3} / \text { det }\right)\end{array}$} & \multicolumn{2}{|c|}{ Suhu $\left({ }^{\circ} \mathrm{C}\right)$} & \multirow{2}{*}{$\mathrm{pH}$} & \multirow{2}{*}{$\begin{array}{c}\mathrm{DO} \\
(\mathrm{mg} / \mathrm{L})\end{array}$} & \multirow{2}{*}{$\begin{array}{c}\text { BOD } \\
(\mathrm{mg} / \mathrm{L})\end{array}$} \\
\hline & & & Udara & Air & & & \\
\hline 1 & Waduk Riam Kanan & - & 28,0 & 27,5 & 6,70 & 6,95 & 2,76 \\
\hline 2 & PLTA Ir. P. M. Noor & 15,53 & 27,5 & 25,5 & 6,27 & 6.27 & 2,91 \\
\hline 3 & Desa Tambela Sari & 96,58 & 27,0 & 26,0 & 6,56 & 4,79 & 1,77 \\
\hline 4 & Desa Tambela & 106,31 & 27,5 & 25,5 & 6,13 & 4,58 & 2,06 \\
\hline 5 & Desa Awang Bangkal & 65,31 & 27,0 & 26,5 & 6,26 & 3,73 & 2,24 \\
\hline 6 & Desa Mandi Kapau & 86,15 & 26,5 & 24,5 & 6,24 & 2,86 & 1,33 \\
\hline 7 & Bendungan Irigasi & 147,72 & 27,0 & 25,5 & 6,24 & 2,34 & 1,16 \\
\hline \multirow[t]{2}{*}{8} & Desa Sungai Asam & 66,5 & 27,0 & 25,5 & 6,33 & 6,03 & 1,84 \\
\hline & Baku Mutu Lingkungan * & - & \multicolumn{2}{|c|}{ $\pm 3^{\circ}$ suhu udara } & $6-9$ & Min. 6 & Maks. 2 \\
\hline
\end{tabular}

*) PP No. 82 tahun 2001 untuk Air Kelas I

Waduk Riam Kanan memiliki luas daerah genangan 9.200 ha dan berada pada ketinggian 62 meter diatas permukaan laut[7]. Waduk Riam Kanan merupakan lokasi awal tempat pengambilan sampel, dengan tujuan untuk menggambarkan kondisi awal kualitas air Sungai.

Tidak dilakukan pengukuran debit, dikarenakan dimensi waduk yang luas dan dalam serta kecepatan aliran yang tidak dapat diukur. Dalam ekosistem perairan, suhu air dan udara, tekanan udara, ketinggian area, kekeruhan, salinitas, turbulensi air, dan biota perairan merupakan faktor yang secara alamiah berpengaruh terhadap penurunan kadar DO. Suhu air yang lebih tinggi menyebabkan kadar DO dalam air semakin rendah[8]. Pada suhu $27,5^{\circ} \mathrm{C}$ dan tekanan $760 \mathrm{mmHg}$ titik jenuh kadar DO seharusnya adalah 7,89 $\mathrm{mg} / \mathrm{L}$, selisih kadar DO tersebut menunjukkan adanya penggunaan oksigen untuk aktifitas penguraian bahan kimia di dalam air, karena di titik tersebut juga terukur BOD sebesar 2,76 ppm (melebihi baku mutu). Kadar DO di lokasi ini menunjukkan dimensi badan air terutama luas permukaan sangat berpengaruh terhadap tangkapan oksigen, walaupun secara topografi posisi waduk berada lebih tinggi dibandingkan lokasi lainnya. Kadar BOD yang melebihi baku mutu dapat di sebabkan adanya buangan limbah dari aktivitas penduduk dan keramba ikan disekitar waduk.

Waduk Riam Kanan digunakan untuk menggerakan mesin turbin pada PLTA Ir. P. M. Noor. Lokasi pengambilan sampel dilakukan pada jarak $370 \mathrm{~m}$ dari lokasi pengambilan waduk Riam Kanan. Lokasi pengambilan sampel ini untuk 
menggambarkan kondisi kualitas air sungai setelah pemanfaatan PLTA.

Hasil pengukuran menunjukan $\mathrm{pH}$ air masih memenuhi baku mutu. Aliran air yang melewati PLTA Ir. P. M. Noor digunakan hanya untuk aktivitas pemutaran tubin. Hasil pemeriksaan kadar BOD yang sedikit lebih tinggi dari lokasi sebelumnya yaitu $2,91 \mathrm{mg} / \mathrm{L}$, dan kadar DO turun menjadi $6,27 \mathrm{mg} / \mathrm{L}$. Penurunan kadar DO diduga akibat berkurangnya kontak air dengan udara pada saat air memasuki ruang turbin. Faktor lainnya adalah penyempitan permukaan badan air dari bendungan ke aliran sungai. Pergerakan air yang turun dari waduk menyebabkan lompatan hidrolis yang memungkinkan tertangkapnya oksigen di udara, namun di saat yang sama air yang jatuh secara vertikal menyebabkan turbulensi dengan dasar sungai dan berpotensi mengangkat material organik yang terdapat di dasar sungai.

Desa Tambela Sari merupakan desa pertama yang berada di aliran sungai Riam Kanan. Lokasi ini berjarak 1,9 km dari lokasi pengambilan sampel di PLTA Ir. P. M. Noor $( \pm 2,27 \mathrm{~km}$ dari Waduk Riam kanan). Tujuan pengambilan sampel pada lokasi ini untuk menggambarkan kualitas air sungai pada kondisi awal dimulainya aktifitas keramba ikan dan rumah tangga.

Terdapat peningkatan debit aliran dan $\mathrm{pH}$ air, dikarenakan adanya tambahan volume air yang berasal dari anak sungai Kembang. Di lokasi ini kadar DO 4,79 mg/L dan BOD 1,77 mg/L. Hasil pengukuran menunjukkan kadar DO tidak memenuhi baku mutu. Penurunan kadar DO seharusnya diikuti dengan peningkatan kadar BOD, namun kenyataannya kadar BOD juga mengalami penurunan. Hal ini menunjukkan BOD bukan faktor utama penyebab turunnya kadar DO. Penurunan kadar DO dapat disebabkan karena adanya aktivitas keramba ikan dan sampah domestik. Jumlah keramba di antara waduk dan desa Tambelasari mencapai 121 buah. Terdapat jalur kosong sepanjang $\pm 1000 \mathrm{~m}$ sebelum aktivitas keramba ikan yang memungkinkan air melakukan self purification, yang dapat menurunkan kadar BOD.
Lokasi pengambilan sampel pada Desa Tambela berjarak 1,4 km dari lokasi pengambilan sampel di Desa Tambela Sari $( \pm 3,67 \mathrm{~km}$ dari Waduk Riam Kanan). Tujuan pengambilan sampel pada lokasi ini untuk menggambarkan kualitas air sungai pada kondisi aktivitas keramba ikan dan rumah tangga mulai meningkat.

Terdapat peningkatan debit aliran dan hasil pengukuran $\mathrm{pH}$ masih dalam baku mutu. Penurunan $\mathrm{pH}$ dari lokasi sebelumnya, dapat disebabkan karena adanya aktivitas keramba yang menyababkan terjadinya penguraian bahan anorganik dan organik dari sisa pakan ikan dan ikan yang mati. Di lokasi ini kadar DO sedikit berkurang dibandingkan lokasi sebelumnya, sedangkan kadar BOD sebesar 2,06 mg/L. Nilai DO dan BOD tersebut tidak memenuhi baku mutu. Seperti halnya di desa Tambela Sari, sumber utama pencemaran bahan kimia di Desa Tambela berasal dari keramba dan sampah domestik. Permukiman di sisi sungai Desa Tambela tidak sebanyak desa Tambala Sari namun jumlah keramba yang ada di sungai jauh lebih banyak $( \pm 504$ buah) dan memenuhi ruas sungai. Kondisi ini sedikit tertolong dengan banyaknya tikungan dan jeram yang membantu permukaan air menangkap oksigen dari udara.

Desa awang Bangkal berada pada daerah yang lebih rendah. Aktifitas keramba ikan dan rumah tangga meningkat, jika dibandingkan pada desa Tambela Sari dan Desa Tambela. Lokasi pengambilan sampel berjarak $\pm 2,9 \mathrm{~km}$ dari lokasi pengambilan sampel di Desa Tambela $( \pm 6,60 \mathrm{~km}$ dari Waduk Riam Kanan). Tujuan pengambilan sampel pada lokasi ini untuk menggambarkan kualitas air sungai pada kondisi aktifitas keramba ikan dan rumah tangga paling banyak.

Terdapat penurunan debit aliran ,hal ini dimungkinkan karena adanya peningkatan pemanfaat aliran sungai untuk keperluan air bersih warga, dan terjadinya pendangkalan sungai (kedalaman sungai 1,80 m). Penumpukan limbah rumah tangga dan aktivitas keramba ikan dapat menyebabkan sedimentasi didasar sungai. Hasil pengukuran $\mathrm{pH}$ masih dalam baku mutu. 
Peningkatan pH dari lokasi sebelumnya, dapat disebabkan karena adanya aktivitas jamban (MCK) yang menghasilkan limbah sabun dan deterjen yang bersifat basa.

Kadar DO dan BOD pada lokasi ini tidak memenuhi baku mutu. Kadar DO hanya sebesar $3,73 \mathrm{mg} / \mathrm{L}$, sedangkan kadar BOD sebesar 2,24 mg/L. Sungai di antara desa Tambela dan Awang Bangkal merupakan lokasi paling banyak menerima beban cemaran, karena jumlah rumah dan keramba ikan terkonsentrasi di wilayah ini. Tercatat sebanyak 678 keramba ikan terbentang dari hulu ke hilir.

Lokasi pengambilan sampel berjarak $\pm 3,6 \mathrm{~km}$ dari lokasi pengambilan sampel di Desa Awang Bangkal $( \pm 10.245 \mathrm{~m}$ dari Waduk Riam Kanan). Pada lokasi ini terdapat banyak tanaman enceng gondok, aktifitas keramba ikan, dan aktifitas penambangan pasir dan batu koral, sehingga tujuan pengambilan sampel pada lokasi ini untuk menggambarkan kualitas air sungai akibat aktifitas keramba ikan, rumah tangga dan penambangan pasir dan batu koral.

Terjadi peningkatan debit aliran, karena adanya penambahan volume dari anak sungai yang ada pada lokasi ini. Hasil pengukuran $\mathrm{pH}$ air masih dalam baku mutu, dan terjadi sedikit penurunan $\mathrm{pH}$ air dari lokasi sebelumnya. Kadar DO tidak memenuhi baku mutu, yaitu hanya sebesar 2,86 mg/L, sedangkan kadar BOD sebesar 1,3 ppm. Sungai di antara Desa Awang Bangkal dan Mandikapau memiliki kedalaman yang tinggi dan paling luas permukaannya, namun kecepatan alirannya paling rendah dan sebagian besar permukaan air ditutupi oleh eceng gondok. Jumlah keramba ikan di antara kedua titik ini masih cukup banyak yaitu 553 keramba. Beberapa ratus meter sebelum lokasi pengambilan sampel terdapat kegiatan penambangan pasir dan batu koral yang menyebabkan peningkatan kekeruhan, hal ini dapat menyebabkan penurunan kelarutan oksigen didalam air.

Bendungaan Irigasi Karang Intan, berada di Mandikapau Kecamatan Karang Intan dengan luas wilayah genangan 462 ha. Lokasi ini berjarak $1.37 \mathrm{~km}$ dari lokasi pengambilan di desa mandikapau $(11,612$ km dari Waduk Riam Kanan). Tujuan pengambilan sampel pada lokasi ini untuk menggambarkan kondisi kualitas air akibat aktifitas penambang pasir dan koral.

Terjadi peningkatan debit aliran yang dimungkinkan karena adanya penambahan volume dari anak sungai yang ada pada lokasi ini. Hasil pengukuran suhu dan pH air masih dalam baku mutu. Kadar DO terukur sebesar 2,34 mg/L atau $-5,85$ dari keadaan jenuhnya, sedangkan kadar BOD sebesar 1,16 mg/L. Kondisi sungai di lokasi ini dengan lebar permukaan yang luas, kedalaman air tinggi, tetapi kecepatan aliran rendah. Menurut laporan masyarakat ikan keramba di wilayah ini tidak dapat tumbuh dengan baik sehingga jumlah keramba yang dikembangkanpun sangat sedikit (22 buah). Hal ini terkait dengan keterbatasan oksigen terlarut yang dibutuhkan dalam pertumbuhan ikan. Rendahnya kadar DO di lokasi ini diduga merupakan akumulasi dari cemaran organik di bagian hulu.

Lokasi ini berjarak $1,8 \mathrm{~km}$ dari bendungan Irigasi Karang intan $(13,41 \mathrm{~km}$ dari Waduk Riam Kanan). Sebelum lokasi pengambilan sampel sudah tidak terdapat lagi aktifitas penambangan pasir dan koral, dan aktifitas keramba ikan mulai meningkat. Tujuan pengambilan sampel di lokasi ini untuk menggambarkan kondisi awal dimulainya kembali aktifitas rumah tangga dan keramba ikan.

Terjadi penurunan debit aliran, yang disebabkan adanya pemanfaatan aliran sungai untuk keperluan irigasi pada lokasi sebelumnya. Hasil pengukuran $\mathrm{pH}$ air masih dalam baku mutu, dan terjadi peningkatan $\mathrm{pH}$ air yang mungkin disebabkan kemampuan alam dalam memperbaiki kondisinya (self purification). Hal ini juga ditunjukkan dengan kadar DO meningkat tajam yaitu $6,03 \mathrm{mg} / \mathrm{L}$, dan kadar BOD sebesar 1,84 $\mathrm{mg} / \mathrm{L}$.

Data hasil pengukuran variabel debit aliran pada lokasi pengambilan sampel Waduk Riam Kanan tidak dapat dilakukan, sehingga analisis hubungan antara variabel bebas dan terikat 
dilakukan hanya pada lokasi : 1) PLTA Ir. P. M. Noor, 2) Desa Tambela Sari, 3) Desa Tambela, 4) Desa Awang Bangkal, 5) Desa
Mandikapau, 6) Bendungan Irigasi Karang intan, dan 7) Desa Sungai Asam, dengan hasil analisis sebagai berikut :

Tabel 2. Hasil Anaisis korelasi spearman antara variabel bebas (jarak antar lokasi, jumlah keramba dan debit aliran) dengan variabel terikat ( $\mathrm{pH}, \mathrm{DO}$ dan BOD)

\begin{tabular}{clccc}
\hline \multirow{2}{*}{ No. } & \multicolumn{2}{c}{ Variabe bebas } & \multicolumn{3}{c}{ Variabel terikat dan Sig. (2-taied) } \\
& & $\mathrm{pH}$ & $\mathrm{DO}$ & 0.294 \\
$\mathrm{BOD}$ & 0.702 & 0.180 \\
2 & Jarak lokasi sampel & 0.531 & 0.229 & 0.908 \\
3 & Jumlah Keramba & 0.180 & 0.036 & 0.007 \\
\hline
\end{tabular}

*. Correlation is significant at the 0.05 level (2-tailed).

Dari hasil uji korelasi spearman, hanya variabel terikat debit aliran yang memiliki hubungan korelasi dengan DO (sig. 0.036) dan BOD (sign. 0.007) pada level signifikan korelasi sebesar 0.05 . Hal ini menunjukkan bahwa debit aliran yang diperoleh dari data lebar, kedalaman sungai dan kecepatan aliran sungai memiliki pengaruh terhadap parameter DO dan BOD. Banyaknya oksigen yang ditangkap dari permukaan air, di pengaruhi oleh lebar dan kecepatan aliran sungai, dan DO akan mempengaruhi aktivitas mikroorganisme (kadar BOD) di dalam air. Penambahan volume air karena adanya anak sungai juga akan mempengaruhi debit aliran dan dapat menyebabkan pengenceran bahan pencemar di dalam air ${ }^{[2][9] .}$

Anaisis spasial dilakukan untuk menggambarkan hubungan jumlah keramba dengan parameter kadar DO dan BOD berdasarkan data sistem informasi geografis (SIG) dengan aplikasi program quantum GIS. Hanya kadar DO yang berkorelasi dengan jumlah keramba ikan dengan hasil sebagai berikut :

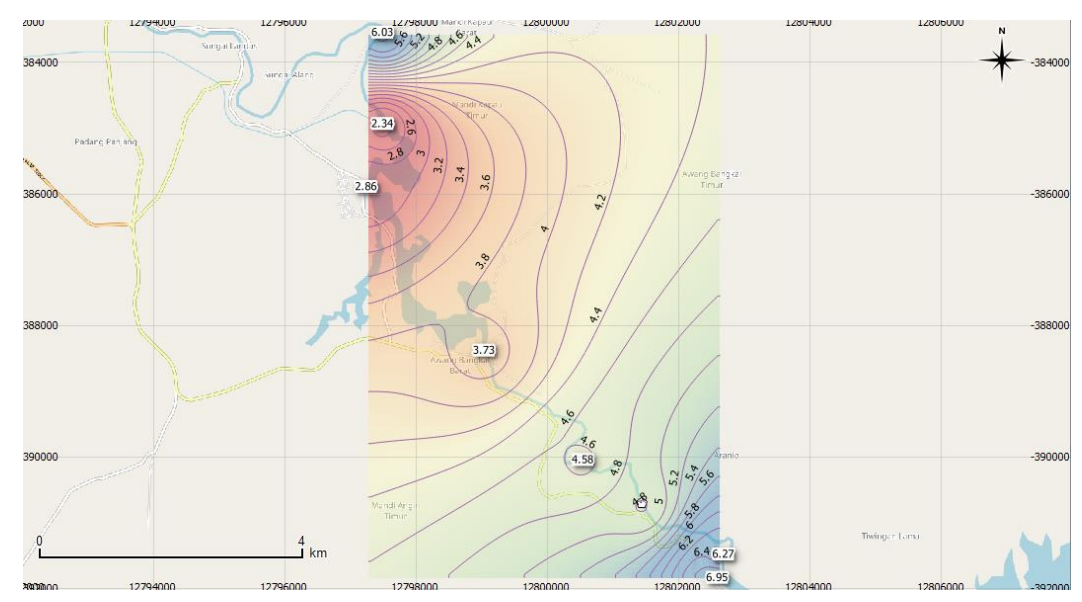

Gambar 2. Kontur Kadar DO (Citra Satelit OpenStreetMap, 2017)

Gambar 2. menujukkan pola kadar DO di sungai Riam Kanan berkorelasi negatif dengan jumlah keramba ikan. Semakin ke hilir, semakin banyak dan terakumulasi polutan organik maka semakin rendah kadar DO di dalam sungai.

\section{KESIMPULAN DAN SARAN}

Hasil pengukuran debit aliran Sungai Riam Kanan pada lokasi pengambilan sampel berkisar antara 15,53 hingga $147,72 \mathrm{~m}^{3} /$ detik dan kualitas air dengan parameter $\mathrm{pH}$ antara 6,13-6,70, kadar DO antara 2,34-6,95 mg/L dan kadar BOD antara 1.16-2,91 mg/L.

Berdasarkan hasil uji statistik terdapat korelasi antara debit alitan 
dengan kadar DO (sig. 0.036) dan kadar BOD (sig. 0.007) pada level signifikan korelesai sebesar 0.05. Hasil analisis spasial menunjukkan pola kadar DO di sungai Riam Kanan berkorelasi negatif dengan sumber pencemar (keramba ikan).

Dapat disaranakan kepada pihak terkait untuk melakukan pengaturan dan pengawasan terhadap aktivitas keramba ikan dan penambangan koral dan pasir yang ada disepanjang aliran Sungai Riam Kanan agar tidak memperburuk kualitas air sungai, dan perlu dilakukan pengerukan terhadap sedimen, terutama pada daerah yang telah mengalami pendangkalan sungai.

\section{KEPUSTAKAAN}

1. Widodo. H, 2014. Debit Air Riam Kanan Menyusut, Ribuan Ekor Ikan MatiInternet, diakses pada Minggu, 14 Agustus 2016, http://banjarmasin. tribunnews.com /2014/09/16/ debit-air-riam-kanan- menyusutribuan-ekor-ikan-mati.

2. Hendrasarie, N. and Cahyarani, 2010. Kemampuan Self Purification Kali Surabaya, Ditinjau dari Parameter Organik Berdasarkan Model Matematis Kualitas Air [Journal]. Surabaya: Jurnal Ilmiah Teknik Lingkungan, 2010. - 1 : Vol. 2.

3. BSN, 2004. Metoda Pengambilan Contoh Air Permukaan, SNI 6989.572004.
4. BSN, 2004. Tata Cara Pengambilan Contoh Dalam Rangka Pemantauan Kualitas Pada Suatu Daerah Pengaliran Sungai, SNI 03-7016-2004, 2004.

5. Wahyuni, et. al. 2011. Studi Kasus Sungai Riam kanan Di Desa Awang Bangkal Kecamatan karang intan Kabupaten Banjar. (Jurnal), Enviro Science 7 (2011) 88-92.

6. Novitasari, 2012. Kajian Pengelolaan Sumber Daya Air (Studi Kasus Hulu DAS Martapura Sub Das Riam Kanan), (Jurnal), Info Teknik, Volume 13 No. 1 Juli 2012

7. Tini, S. 2000. Kajian Peluang Curah Hujan Bulanan Dan Perkiraan Hasil Tambahan Air Sebagai Bahan pertimbangan Penentuan waktu Pelasanaan Modifiksi Cuaca (Hujan Buatan) Kasus: DAS Riam kananKalimantan Selatan, Jurnal Sains \& Teknologi Modifikasi Cuaca, Vol. 1, No. 2, 2000:143-152.

8. Fardiaz Srikandi. 1992. Polusi Air Dan Udara. Penerbit Kanisius. Yogyakarta

9. Salmin, 2005. Oksigen Terlarut (DO) Dan Kebutuhan Oksigen Biologi (BOD) Sebagai Salah Satu Indikator Untuk Menentukan Kualitas Perairan, Jurnal Oseana, Volume XXX, Nomor 3, 2005. 
